\title{
Perspectives
}

\section{Governance implications of attracting external equity investors in private family firms}

\begin{tabular}{|r|l|}
\hline Journal: & Academy of Management Perspectives \\
\hline Manuscript ID & AMP-2017-0204.R2 \\
\hline Document Type: & Symposium \\
\hline Keywords: & $\begin{array}{l}\text { Corporate governance < Social Issues in Management < Topic Areas, } \\
\text { Family enterprises < Entrepreneurship < Topic Areas, Governance }< \\
\text { Entrepreneurship < Topic Areas, Stockholders/investors < Upper } \\
\text { Echelons/ Corporate Governance < Business Policy and Strategy < Topic } \\
\text { Areas }\end{array}$ \\
\hline \multicolumn{2}{l}{} \\
\hline
\end{tabular}




\title{
GOVERNANCE IMPLICATIONS OF ATTRACTING EXTERNAL EQUITY INVESTORS IN PRIVATE FAMILY FIRMS
}

\author{
Abstract \\ While research commonly assumes business-owning families are concerned about the \\ preservation of control, more and more families seek cooperation with external investors to \\ accomplish firm- and/or family level-goals. In this paper, we provide a conceptual configuration \\ of the different governance scenarios that may arise when family owners attract outside capital. \\ Combining two important family objectives - its objective to provide liquidity either to the \\ family or to the firm, and its objective to cede or to retain long-term family control - we identify \\ four scenarios with different governance implications and preferred types of external investors. \\ Our analysis contributes to an increased understanding of the evolving structures of ownership in \\ private family firms, the effectiveness and efficiency of governance arrangements in family firm- \\ external investor cooperations and the increasingly heterogeneous private equity funding \\ landscape. \\ Keywords: corporate governance, family firms, private equity, alternative investors, \\ governance configurations
}




\section{GOVERNANCE IMPLICATIONS OF ATTRACTING EXTERNAL EQUITY INVESTORS IN PRIVATE FAMILY FIRMS}

While it is commonly assumed that family firms are reluctant to hand over control to outside investors (La Porta, Lopez-De-Silanes, \& Shleifer, 1999; Mahérault, 2004; Poutziouris, 2001; Wu, Chua, \& Chrisman, 2007), more and more private family firms open their capital for external investors (Battistin, Bortoluzzi, Buttignon, \& Vedovato, 2017; Dawson, 2011; Wessel, Decker, Lange, \& Hack, 2014). This evolution is driven by trends in both the demand and supply of capital. Family firms increasingly consider equity investments because more stringent capital and liquidity regulations such as Basel III have made longer term bank lending to these firms, which are often smaller, less attractive (OECD, 2012). Furthermore, many business owners who are reaching retirement age seek investors to diversify their wealth or to accomplish transgenerational successions. At the same time, new 'players' such as family offices and high net worth individuals (HNWIs) increasingly invest in private family firms (Rottke \& Thiele, 2017), in addition to established investors such as private equity (PE) firms ${ }^{1}$. For example, European family offices nearly doubled their direct investments in private companies between 2008 and 2014 (Campden Research \& UBS, 2015).

The role of external investors in private family firms has only received limited attention in the academic literature. Some studies examined PE buyouts of family firms (Howorth, Westhead, \& Wright, 2004; Scholes, Wright, Westhead, \& Bruining, 2010) or external ownership transitions of family firms more generally (Wennberg, Wiklund, Hellerstedt, \&

\footnotetext{
${ }^{1} \mathrm{PE}$ is defined as risk capital provided by professional investors to mature, unquoted private businesses (Invest Europe, 2017). PE involves medium to long-term investments (generally three to seven years), characterized by active ownership. Investors in PE funds are principally institutional investors, such as insurance companies and pension funds.
} 
Nordqvist, 2011; Wiklund, Nordqvist, Hellerstedt, \& Bird, 2013), whereby the family fully exits the firm and control is ceded to new owners. However, few studies examined scenarios where families do not cede full control but instead seek cooperation and thereby share control with investors to accomplish their goals. Similarly, the PE literature mainly focuses on PE-backed buyouts, often of public firms, but much less on investments in private firms, including minority investments. Additionally, the important role of alternative investors such as family offices in ownership transitions of private family firms has largely been neglected.

The question how investors can contribute to private family firms is not only empirically relevant but also theoretically intriguing. Following the management and finance literatures, investors and family owners may not be the best partners as they are assumed to hold considerably different objectives. Investors such as PE firms invest in a portfolio of firms and focus on the maximization of a economic value in the medium term (Kaplan \& Strömberg, 2009; Wood \& Wright, 2009). Family owners, in contrast, typically have their wealth concentrated in one firm and have long-term objectives that are not always economic in nature (Berrone, Cruz, \& Gómez-Mejía, 2012; Chrisman, Chua, Pearson, \& Barnett, 2012). These different objectives might lead to principal-principal conflicts (Young, Peng, Ahlstrom, Bruton, \& Jiang, 2008). Therefore, more insights in ownership transitions and related governance mechanisms in private family firms are key to better understand transitions or cooperations between families and equity investors (Uhlaner, Wright, \& Huse, 2007).

To enrich our understanding of the role of different investor types for private family firms, this paper provides a conceptual configuration of the governance scenarios that may arise when a family decides to attract external shareholders alongside the family shareholders. We propose that two family objectives will strongly govern such transaction: the family's motivation 
to provide liquidity either to the firm or to the family, and the family's degree of transgenerational intent. The first objective distinguishes transactions that increase the equity capital of the firm and where family shareholders keep their equity and transactions that involve a transfer of some, but not all, shares from the family to an external equity investor. The second objective distinguishes between scenarios where a family aims to exit the firm in the foreseeable future, and scenarios where a family aims to keep the firm within the family over generations. Combining these two objectives, we configure external investments in family firms into four scenarios. For each scenario, we provide examples, discuss governance implications for firm ownership and the level of fit with different types of investors. Regarding governance implications, we discuss the wealth concentration and investment time horizon of the remaining family, the family's focus on socioemotional wealth (SEW), the focus on efficiency and/or growth as drivers of firm performance, the use of debt to structure the transaction, family involvement in management, and the importance of relational governance. We thereby take a configurational perspective, proposing that these governance attributes and the type of investor (such as independent PE, government-funded PE or family offices) interact in complementary ways as part of unique configurations to facilitate successful ownership transitions (Meyer, Tsui, \& Hinings, 1993). The notion of configuration is used to theorize what governance mechanisms are likely to lead to the fulfilment of desired objectives of family owners on the one hand and investors on the other hand.

We make several contributions to the research literature. First, our configurational model increases understanding about the evolving structures of ownership in private family firms. Ownership in private firms is theoretically intriguing because it is relatively illiquid and owners tend to be deeply involved in and identify with their firms. The insights also call for research that 
takes new theoretical perspectives to study owner dynamics in private firms. While research in this area is largely dominated by agency theory (Battistin et al., 2017; Chrisman, Chua, Steier, Wright, \& McKee, 2012; Daily, Dalton, \& Cannella, 2003), our model calls for better integrations with alternative theoretical perspectives. Second, our study contributes to the family business literature by examining gradual transitions from a family to a non-family firm. To date, scholars have paid substantially more attention to the minority of family firms that transition to another generation of family members than the majority of family firms that does not (Wennberg et al., 2011), leaving substantial gaps in our understanding of ownership transition in family firms (Wiklund et al., 2013). Third, our framework increases understanding about the increasing heterogeneity among PE investors and the role of alternative investors such as family offices and HNWIs. Despite their practical relevance, these investors only received limited attention in the research literature so far (Neckebrouck, Manigart, \& Meuleman, 2017; Wessel et al., 2014).

\section{THEORETICAL BACKGROUND}

\section{Family Firm Objectives and Decision-Making}

Family firms are characterized by the existence of individuals, related by family ties, who exert substantial influence on the company, either via ownership stakes or important management positions (König, Kammerlander, \& Enders, 2013). Although exact numbers for the prevalence of family firms vary, research consistently shows that family firms dominate economies around the world (La Porta et al., 1999).

The governance and conduct of family firms has been studied from a variety of theoretical perspective including mainstream management theories such as agency theory, 
stewardship theory, and the resource-based view. ${ }^{2}$ Agency theory implies that family firms have higher performance because they have lower agency costs related to the separation of ownership and control (Demsetz \& Lehn, 1985; Fama \& Jensen, 1983). Yet, agency theory also asserts that family owners are risk-averse because they typically hold concentrated wealth positions ( $\mathrm{La}$ Porta et al., 1999; Morck \& Yeung, 2003), misuse their power to expropriate minority shareholders (Claessens, Djankov, \& Lang, 2000), and are prone to nepotism (Chrisman, Sharma, Steier, \& Chua, 2013), executive entrenchment (Volpin, 2002), and intra-family conflict (Schulze, Lubatkin, Dino, \& Buchholtz, 2001). Stewardship, in contrast, suggests that family owners act as farsighted stewards of their business (Le Breton-Miller, Miller, \& Lester, 2011; Neckebrouck, Schulze, \& Zellweger, 2018) and care about the long-term wellbeing of all stakeholders (Davis, Allen, \& Hayes, 2010). The resource-based view maintains that family firms possess unique resources, which they leverage to benefit performance (Nordqvist, 2005; Sirmon \& Hitt, 2003).

Next to these mainstream theories, over the last decade, the socioemotional wealth (SEW) perspective developed as a dominant theoretical paradigm in the family business field. Profit generation is rarely the exclusive goal for controlling-ownership families. Meeting the nonfinancial social and emotional needs also is an inherent goal of family firms. This is referred to as the unique family firm phenomena called SEW. SEW encompasses a variety of aspects including the employment of family members (Firfiray, Cruz, Neacsu, \& Gomez-Mejia, 2017; Gómez-Mejía, Cruz, Berrone, \& De Castro, 2011), enjoyment of family influence over the business (Gómez-Mejía, Haynes, Núñez-Nickel, Jacobson, \& Moyano-Fuentes, 2007),

\footnotetext{
${ }^{2}$ Other theoretical perspectives include transaction cost theory (Gedajlovic \& Carney, 2010; Verbeke \& Kano, 2012), identity theory (Cannella, Jones, \& Withers, 2015; Miller, Le Breton-Miller, \& Lester, 2011), and embeddedness (Aldrich \& Cliff, 2003; L. P. Steier, Chua, \& Chrisman, 2009).
} 
reputational advantages from being associated with the firm (Deephouse \& Jaskiewicz, 2013), and the preservation of benevolent ties among family members (Cruz, Gómez-Mejia, \& Becerra, 2010).

The key assumption of the SEW perspective is that the preservation of SEW represents a primary driver of family firm decision making (Gómez-Mejía, Makri, \& Kintana, 2010). For example, family firms invest less in R\&D (Gómez-Mejía et al., 2011) and engage less in corporate diversification (Anderson \& Reeb, 2003; Gómez-Mejía et al., 2010) because such decisions entail losses of SEW, for instance because they require the family to attract outside managerial talent thereby reducing family control over the enterprise. More recent refinements nuance the view that family firms are foremost concerned with SEW goals arguing that family owners weigh implications of their decisions on financial wealth and SEW in tandem (GómezMejía, Patel, \& Zellweger, 2018; Kotlar, Signori, De Massis, \& Vismara, 2018).

Importantly, family firms are heterogeneous in the extent to which they pursue SEW objectives. Conceptually, SEW is inherently linked to the extent of family control over the firm and the degree of familial identification with the firm (Gómez-Mejía et al., 2007). Smaller, privately held family firms focus more on SEW than larger publicly listed family firms because familial identification, influence and personal investment is generally higher in the former (Gómez-Mejía et al., 2011). Control of the firm is critical because it is what allows the family to pursue its interests through the firm (Carney, 2005).

\section{Family Firms and Financial Decision-Making}

Early studies on family firm financing have drawn from normative capital structure theories such as the pecking order theory or the trade-off theory (King \& Santor, 2008; LópezGracia \& Sánchez-Andújar, 2007). When applied to family firms, however, traditional capital 
structure theories often lead to inconclusive results because their assumptions about rational economic behavior may not apply to family firms in which decision making is frequently influenced by non-economic family goals (e.g., Koropp, Grichnik, \& Kellermanns, 2013).

Studies with a background in the strategic management literature suggest that capital structures may reflect the diverse personal goals of decision makers (Barton \& Gordon, 1987, 1988). Several studies find that the financial logic in family firms is influenced by personal preferences of family decision makers, leading to differences between family firm financing and nonfamily firm financing (Gallo, Tàpies, \& Cappuyns, 2004; Romano, Tanewski, \& Smyrnios, 2001). Family firms, for instance, are less likely than nonfamily firms to relinquish control to outside investors because families not only derive financial but also socioemotional value from their firms (Gómez-Mejía et al., 2007).

While informative, the analysis of differences between family and nonfamily firm financing policies ignores the heterogeneity of financing decisions within the population of family firms. More recent research shows that a family firm's usage of debt is influenced by family governance characteristics such as ownership dispersion (Schulze, Lubatkin, \& Dino, 2003a), generational stage (Molly, Laveren, \& Jorissen, 2012), managerial succession (Amore, Minichilli, \& Corbetta, 2011), and owner-manager attitudes (Koropp et al., 2013). However, these studies have primarily focused on the usage of debt and largely neglected equity as a form of financing. This is surprising, as raising equity from non-family members has significant implications for control and governance.

Research on the role of $\mathrm{PE}$ as equity provider for family firms is in its infancy. PE investments are traditionally viewed from an agency perspective with emphasis on obtaining efficiency improvements (Renneboog, Simons, \& Wright, 2007); although, PE can also be a 
vehicle for strategic renewal that fosters upside entrepreneurial growth (Wright, Hoskisson, Busenitz, \& Dial, 2000).

Studies on the role of PE in family firms mostly examine buyouts of family firms wherein the family sells its full ownership stake to PE (Howorth et al., 2004; Scholes et al., 2010). Some studies analyze the selection criteria used by PE when investing in family firms (Dawson, 2011) or valuation particularities of family firms (Ahlers, Hack, \& Kellermanns, 2014). Other studies analyze the process of professionalization of family firms post buyout (Howorth, Wright, Westhead, \& Allcock, 2016), and the resulting impact of PE buyouts on the performance and growth of former family firms (Battistin et al., 2017; Croce \& Martí, 2016; Scholes et al., 2010).

Limited attention, however, has been given to scenarios in which private family firms do not cede full control to investors but instead seek cooperation with investors to accomplish their goals (Neckebrouck, Manigart, \& Meuleman, 2016). Investors hereby may acquire a minority stake in the family business, while the family remains the majority shareholder. This is in contrast with full buyouts, where PE investors typically acquire a controlling majority stake. A key question in this scenario is how potentially divergent goals may lead to principal-principal conflicts (Martin, Gómez-Mejía, Berrone, \& Makri, 2017; Young et al., 2008). Villanueva and Sapienza (2009) suggest that the identity of formal, financially oriented investors, such as PE firms, is unlikely to fit well with family firms. Because family owners often value the preservation of SEW next to the maximization of financial wealth, conflicts between PE investors and the family may arise. Such conflicts might be limited when the firms perform well but can be especially prevalent when the firm underperforms (Martin et al., 2017).

Even if partnering between private family firms and financial investors involves a risk of conflict, recent evidence indicates that more and more private family firms open their capital to 
investors (Battistin et al., 2017). A key question, therefore, is what are the governance implications of a transition from a fully-owned family business to a multiple ownership structure involving outside equity investors (Uhlaner et al., 2007), and what type of investors are most likely to provide a good fit? Using a configurational approach to corporate governance (Meyer et al., 1993; Miles \& Snow, 1978), we propose that 'bundles' of governance practices exist that are consistent with family preferences, firm needs and types of investors (Misangyi \& Acharya, 2014; Rediker \& Seth, 1995). Each configuration is a gestalt of multiple, interlinked, and mutually reinforcing organizational and structural characteristics that are complementary with each other and commonly occur together (Meyer et al., 1993; Miller, Friesen, \& Mintzberg, 1984). Complementarity implies that governance mechanisms mutually reinforce the effectiveness of one another (Schiehll, Lewellyn, \& Muller-Kahle, 2017). In the remainder of this paper we use the notion of configurations to reflect on the effectiveness and efficiency of different governance constellations in collaborations between family firms and investors.

\section{CONFIGURATION MODEL}

We now focus on transactions in which a traditional PE investor or an alternative investor, such as a family office or HNWI, acquires a shareholding next to the family. Figure 1 illustrates our configurational framework. The horizontal axis differentiates between transactions in which an investor increases a firm's capital while family owners retain their shareholdings (liquidity for the firm) and transactions in which investors replace family equity and, therefore, some family members decide to sell all or a proportion of their shares (liquidity for the family). The vertical axis differentiates between families who are looking to cede ownership in the medium term (ceding family ownership) and families who aim to retain ownership (enduring family ownership). The evolution of a firm's equity structure over time is illustrated for each 
quadrant. The entry (t1) and exit ( $\mathrm{t} 2)$ time of the investor are marked. In Quadrant 3 and 4, the family remains shareholder after the investor exits at $\mathrm{t} 2$; in Quadrant 1 and 2, the family exits at $\mathrm{t} 2$, often together with the investor.

\section{--- Please insert Figure 1 about here ---}

In the subsections that follow, we describe different transaction types related to these four quadrants, provide examples, and discuss governance implications. We use the notion of configuration to theorize about the ideal constellation of governance characteristics in each quadrant. Specifically, for each quadrant, we reflect on the combination of formal and informal governance mechanisms that will be most efficient and effective in fulfilling the specific economic and/or non-economic objectives of the family and the investor. Following a configurational approach, governance mechanisms in such "ideal deals" must show high levels of fit with the overarching goals and resources of the family and with each other.

Most configurational research defines governance performance solely in terms of efficiency, typically firm profitability (e.g., Misangyi \& Acharya, 2014). In our context, however, it is critical to also assess performance in terms of effectiveness. While efficiency focuses on the relationship between inputs and outputs, effectiveness in our context relates to the extent to which an investment helps a family to achieve its idiosyncratic economic and noneconomic goals. Assessing performance as achievement of goals is particularly important in family firms because of the non-economic goals family firms possess (Chua, 2018).

Our framework is shown in Table 1. In terms of governance implications, we include different factors highlighted in the literature. From a family perspective, we consider the wealth concentration of the remaining family, the family's investment time horizon and the extent to which family owners focus on SEW-objectives. First, the wealth concentration of the remaining 
family is important because owning families, due to their relatively undiversified wealth position, are generally more risk averse toward growth (La Porta et al., 1999). This risk aversion might be a source of conflict with investors who typically have more diversified portfolios and, therefore, a higher risk propensity. Second, owners might have differing time horizons concerning their involvement in a firm potentially causing conflicts of interest (Arthurs, Hoskisson, Busenitz, \& Johnson, 2008). For example, traditional independent PE investors generally seek an exit after three to five years whereas family owners might have a long-term horizon without clear exit intentions. Third, the focus on SEW may direct the family to prioritize non-economic objectives over the objective of wealth maximization that is commonly prioritized by investors (Zellweger, Nason, Nordqvist, \& Brush, 2013). SEW-considerations will influence the family's preference for certain investor types and governance arrangements.

From a firm perspective, we consider a focus on efficiency and/or growth as a main driver of value creation post-investment, the use of debt to structure the transaction and the likelihood that the family will reduce its involvement in firm management. First, increasing efficiency has been one of the central mechanisms for investors such as traditional PE firms to create value (Cumming, Siegel, \& Wright, 2007). However, efficiency-enhancing interventions might involve restructuring activities such as reducing the workforce or replacing family employees that might be detrimental to the family's reputation or SEW and, therefore, be a source of owner conflict. Second, traditional PE investors increasingly focus on growth to generate returns (Hoskisson, Shi, Yi, \& Jin, 2013; Wright, Hoskisson, \& Busenitz, 2001). However, family firms might be reluctant to pursue risky growth strategies which could lead to conflicting objectives and, therefore, requires appropriate governance. Third, a key element of PE governance is the use of debt instruments versus equity (Wright, Amess, Weir, \& Girma, 2009). While all transaction 
types discussed in Table 1 will generally involve the use of equity instruments, some investors might combine traditional equity with debt and debt-like instruments to structure the transaction. Debt instruments typically have few rights of control unless the firm becomes insolvent (Jensen \& Meckling, 1976). From a family perspective, debt-like instruments have the advantage that they require less involvement of investors. However, an excessive use of debt will also increase the likelihood of financial distress and endanger the family's SEW. Fourth, we discuss the likelihood that the family will reduce its involvement in firm management as part of the deal, for instance by giving up the CEO position. The decision to decrease involvement in management may relate to structural family-level considerations (for instance when a family-member CEO is reaching retirement age) but may also relate to economic considerations. The willingness to give up control over management is important because it may influence the type of investor that can be attracted, and the extent to which family owners can derive SEW from their firm following the transaction.

Finally, we discuss the type of investor that is most likely to provide a good fit, and how important relational governance will be in driving the family-investor relationship. Different types of investors clearly have different objectives including investment time horizon, preferred risk profile, the pursuit of non-economic goals (such as investor reputation), active involvement in portfolio firms, and so forth (Cumming, Schmidt, \& Walz, 2010; Drover et al., 2017; Hoskisson, Shi, et al., 2013; Manigart \& Wright, 2013). Following a configurational approach, the performance of outside investments in private family firms will be highest when investor objectives are consistent with the family and firm-level governance factors discussed earlier. A key question that arises in this respect is what type of governance will drive the investor family collaboration. Given the embeddedness of family relationships in family firms, many scholars 
depict family firms as a context in which relational governance based on mutual trust, a shared vision and identity dominates over contractual governance as stipulated in shareholder agreements, incentives and monitoring systems (Arregle, Hitt, Sirmon, \& Very, 2007; Chrisman, Chua, Le Breton-Miller, Miller, \& Steier, 2018; Eddleston, Chrisman, Steier, \& Chua, 2010; Steier, 2001). Compared to nonfamily firms, family firms may be more inclined to establish trusting relationships because they are concerned about long-term stability and the preservation of a favourable reputation (Eddleston \& Morgan, 2014; Stanley \& McDowell, 2014). In contrast, PE investors traditionally rely on formal shareholder agreements to create alignment on economic objectives and to regulate the execution of voting rights or the transfer of shares (Chemla, Habib, \& Ljungqvist, 2007). Even though contractual governance will be essential in all transaction types, contractual governance is ill-suited to address questions that are of managerial and non-economic nature (such as a firm's strategic position, growth aspirations, as well as the preservation of the family's SEW) (Schulze et al., 2001). Overall, relational governance may be key for investors and family owners to work together successfully and, therefore, is a key element of firm governance.

\section{Quadrant 1: Gradual Exit}

Families in Quadrant 1 (Figure 1) seek a gradual exit from their family business. Therefore, they may engage in cooperation with an external investor to diversify some of their wealth in the short term (time $\mathrm{t} 1$ ), while aiming to simultaneously maximize firm value before a final exit (time t2). We define these transactions as gradual exits. Families in this quadrant have no transgenerational intent. The equity investment only involves a partial change in ownership and does not provide extra capital to the firm. 
An example of a gradual exit is the buyout of La Buvette, a French agricultural equipment manufacturer owned by the fifth generation of the Gustin family, in 2003 (Schmohl, 2010). The family felt that their firm still had value creation potential, but they needed a partner to professionalize further. Because there were no successors in the family and because they were concerned about the long-term independence of the firm, the family started negotiations with external investors. The family retained Alliance Entreprendre, a local mid-market bank-affiliated buyout fund, as an investor given its value adding potential, cultural fit, and attractiveness of the financial offer. Following the deal, the family gave up the CEO position and retained a minority stake. Alliance Entreprendre monitored the cash flows of the business closely, introduced more systematic management processes and prepared the business for a joint exit with the family.

Table 1 summarizes key governance implications of transactions in this quadrant and the potential fit with different investor types. From a family perspective, next to family owners who sell all their shares in the transaction, remaining family owners may decide to diversify their wealth by selling some of their shares. This reduces their wealth concentration in the firm and increases the likelihood that the risk profile matches that of investors reducing agency conflicts. Additionally, before investing, investors typically verify which family members want to remain involved in the firm and which want to quit. Investors will buy out family members who do not commit to a joint strategic plan. This will reduce the likelihood of principal-principal conflicts between remaining family members (Schulze, Lubatkin, \& Dino, 2003b). Second, remaining family owners often seek an exit in the medium term when the business has been professionalized. While remaining family owners may have concerns about the preservation of SEW, family owners who do not have intentions for transgenerational control generally have reduced SEW perceptions (Chrisman, Chua, Pearson, et al., 2012; Zellweger, Kellermanns, 
Chrisman, \& Chua, 2012). Reduced expectations about future SEW increase the disposition of family owners toward the maximisation of financial wealth (Kotlar et al., 2018). The maximization of firm value becomes the dominant goal and should lead to a climate in which investors and family owners find a common ground (Villanueva \& Sapienza, 2009). Family owners also become more likely to prioritize economic considerations in their selection of an investor. They may, for instance, prefer an investor who has great value adding skills or a strong reputation, but who does not have a strong familial identity (Cannella, Jones, \& Withers, 2015).

\section{--- Please insert Table 1 about here ---}

From a firm perspective, because these investments do not bring new money in the firm, value will mostly be created by focusing on efficiency gains rather than on growth. Opportunities to increase efficiency are likely present because private family firms frequently base decisionmaking on non-economic personal motives (Gómez-Mejía et al., 2007; Gómez-Mejía, NuñezNickel, \& Gutierrez, 2001) and are vulnerable to poor leadership (Schulze et al., 2001). Investors can help family owners professionalize the governance and financial management of the firm, optimize the business model, cut costs and prepare the business for sale by streamlining organizational processes. We anticipate that families may go a long way in supporting such governance and operational engineering. Nevertheless, when investors do not acquire dominant control over the firm, they might still need to make compromises. Compromises, for instance, may be needed when an investor would want to divest a historically important business division or dismiss underperforming employees who have close emotional ties with the family. Debt financing can be used in these transactions as efficiency improvements should free up cash that can be used to pay off debt and boost returns for the remaining shareholders. Debt provides incentives to implement efficiency-enhancing initiatives (Jensen, 1989). 
Because family owners have a lower focus on SEW, reducing family involvement in management by attracting an external CEO is a viable option in this scenario. Whether or not the family brings in an external CEO will depend on the balance of SEW and economic objectives they wish to pursue after the investment. On one hand, attracting an external CEO implies accepting a greater loss in SEW (Chrisman, Chua, Pearson, et al., 2012). On the other hand, external CEOs will bring external experience and may be more willing to make changes in the firm. Also, family owners who hire an external CEO send a strong signal toward investors that they will direct resources toward financial performance rather than toward the preservation of SEW (Jaskiewicz, Combs, Shanine, \& Kacmar, 2017; Naldi, Cennamo, Corbetta, \& GomezMejia, 2013). Accordingly, the appointment of an external CEO may further reduce principalprincipal problems and allow the family to attract a high-quality investor (Bertrand \& Schoar, 2006).

Overall, deals in Quadrant 1 fit relatively well with the traditional PE-model including independent PE firms and bank-affiliated PE firms. In the traditional model, PE firms are valueenhancing because they increase the managerial focus on the realization of efficiency gains (Jensen, 1993), and bring financial engineering skills which lead to increased leverage (Kaplan, 1989). Independent PE firms have a medium-term investment horizon of three to five years (Wright et al., 2009) which should provide sufficient time to professionalize the firm and implement efficiency-enhancing initiatives. Bank-affiliated PE firms might have an advantage to conduct these type of transactions as they could have obtained private information about their clients through previous banking relationships and may provide them an opportunity to extend more leverage. An important benefit a PE firm could bring to remaining family owners is to provide "cover" for efficiency enhancing actions which might break longstanding implicit 
contracts with, for example, incompetent employees or suppliers (Villalonga, 2012). By

monitoring the underlying target and implementing sound corporate governance practices, $\mathrm{PE}$ firms will help family firms to transition and ultimately facilitate a successful exit (Di Toma \& Montanari, 2012). We anticipate that transactions in this quadrant will be mainly managed with contractual governance and that relational governance will be relatively less important. Because of the family owners' objective to maximize firm economic value and the relatively low focus on SEW, most value the family and the investor will expect to generate from the cooperation will be of a contractable nature.

\section{Quadrant 2: Extend the firm}

In Quadrant 2, families seek a cooperation with an investor to provide capital to the firm (time t1) allowing to jointly maximize firm value before an exit in the medium term (time t2). At time $\mathrm{t} 2$, the family and the investor may jointly exit the firm, the investor can take over the family's stake, or the family may simply sell its stake to another third party. We define these transactions as extend the firm deals. Families are looking to prepare their firm for sale but realize that more resources can help to fully develop their firm. While deals are somewhat like deals in Quadrant 1 because family members plan a medium-term exit, family members retain their shareholding and the investment provides extra capital to firm.

An example of a transaction in this quadrant is the investment of the Business Growth Fund (BGF) in Molecular Products Group, a UK-based manufacturer of advanced chemistrybased products, in 2014 (Private Equity Wire, 2017). At that time, the second-generation family firm had just started to internationalize. BGF helped the family to realize the firm's growth potential by providing additional capital, strengthening the management team and appointing a chairman with relevant experience in acquisitions and major growth initiatives. After the 
operating profits had almost doubled, the family and the investor successfully exited the business with a sale to another PE player in 2017.

Table 1 lists key governance implications. From a family governance perspective, because all family members retain their shareholding, the wealth concentration of family owners remains constant. As such, the family and the investor will differ more in their willingness to take risk than in Quadrant 1. However, like in Quadrant 1, family owners should have somewhat reduced concerns about SEW preservation and will therefore be aligned with investors in their objective to maximize firm value in the medium term. From a firm perspective, because investments in this quadrant bring new money in the firm, investors can create value by focusing on growth next to the realization of efficiency gains and professionalization. To support growth, investors can provide family owners with industry expertise, international relationships, expertise regarding mergers and acquisitions, and so forth (Meuleman, Amess, Wright, \& Scholes, 2009). We anticipate that conflicts between family shareholders and investors will be relatively rare because a focus on growth (rather than efficiency gains) will require fewer changes in existing operations. Nevertheless, investors may need to make compromises when growth-related initiatives involve significant risks. Family owners will generally have higher levels of wealth concentration and therefore a lower risk tolerance. The use of significant debt financing is less likely as the financial obligations associated with debt limit the flexibility needed to pursue growth. Compared to Quadrant 1, families may be somewhat more likely to appoint an external CEO. Because the investor provides extra capital to the firm, value creation will depend on the achievement of profitable growth. Rather than continuing the business 'as usual' and building on the traditional mechanisms, such as financial engineering, to improve performance, value creation should depend more on strategic revitalization (Berg \& Gottschalg, 2005). Family 
owners may look for a new CEO with an entrepreneurial orientation and an attitude toward innovation if the existing family-member CEO does not have the required skill set (Wright et al., 2000).

Overall, deals in this quadrant fit relatively well with the traditional PE-model including independent PE firms and evergreen PE firms. Evergreen PE firms involve funds in which realized investment returns are recycled back into the fund rather than distributed to limited partners and, therefore, the capital committed is permanent. The key benefit of such structure is that it allows for more long-term holding periods compared to traditional PE (Brown \& Kraeussl, 2012). As such, evergreen PE may be especially relevant for families whose exit horizon extends beyond the 3 to 5 years horizon of traditional PE. A longer investment horizon will help to reap the full benefits of the growth scenario, which typically takes longer to achieve compared with efficiency gains as in Quadrant 1. Like in Quadrant 1, family owners and investors will largely align with each other using contractual governance. Relational governance including trust may be somewhat more important, however, because ownership and shareholder agreements are illsuited to ensure alignment on growth-related objectives.

\section{Quadrant 3: Replacement Capital}

Families in Quadrant 3 want to cash (some of) their investment, but also have transgenerational intents. Family owners for instance may seek investors to solve intergenerational transfers with several siblings or other family members. Parents often want to treat their children (or cousins) equally when passing on their firm. But when some family members want to become or remain owner and others do not, investors may help to overcome stalemates by buying the shares of the latter. In this scenario, the succeeding generation has a long-time horizon that likely extends beyond the time horizon of the investor (time t2). 
An example that illustrates this scenario was the buyout of Market Basket, a New England-based supermarket chain owned by the Demoulas family, in 2014. The deal settled a life-long conflict between two family cousins that almost led to the demise of the company. In the deal, one branch of the Demoulas family acquired the $50.5 \%$ stake they did not already own from the other branch with funding from the Blackstone Group and significant amounts of debt (Forbes, 2014).

From a family governance perspective, the wealth concentration of the remaining family will either stay constant or increase. It may increase if the remaining family invests some of its personal wealth to acquire a stake of the selling party. A higher level of wealth concentration might limit the willingness to take risk. Additionally, because family owners may seek to regain full control over their firm in the long-term, they are likely to hold positive expectations about future SEW. Such positive expectations increase the disposition of family owners toward the minimization of SEW losses when considering an investor and related governance arrangements (Kotlar et al., 2018). Family owners will prefer an investor who increases the probability for the family to recover SEW in the long-term (Kotlar et al., 2018).

Because there is no extra capital in the firm, investors need to focus on the realization of efficiency gains to create value. However, because cost reductions often require changing old habits and the family may be more focused on continuity (Allio, 2004), the potential to realize such cost efficiencies may be limited. Given the limited value creation potential, investors will often limit their risk by using a financial structure that emphasizes debt over equity and that guarantees a minimum required return (e.g., mezzanine financing). As family owners will seek to minimize SEW losses when ceding partial ownership, they will be unlikely to appoint an external CEO as part of the transaction. 
Overall, deals in this quadrant do not fit well with the traditional independent PE-model with a closed-end fund. Traditional PE investors and remaining family owners will differ in their concern about SEW, in investment time horizon and risk-willingness. Families will likely prefer investors with a longer time horizon who allow the remaining family to remain in the driving seat and regain control. As highlighted, mezzanine investors may be a good fit, as they will typically not take an active position on the board and will employ financial covenants that tend to be less strict compared to banks (Torpey \& Viscione, 1987) . Initial owners frequently buy out mezzanine investors through the accumulated profits generated by the business or a recapitalisation with inexpensive senior debt. Alternatively, bank-affiliated PE funds or government-funded funds might also be well positioned to invest in this quadrant. Bankaffiliated PE investors might provide funding alongside traditional senior loans provided by the affiliated banks. As bank-related PE investors have lower return expectations than independent PE investors (Manigart et al., 2002), they will also be more willing to provide a debt-like structure. Government-funded PE might sponsor these types of transactions to anchor companies in the local economy and to preserve regional employment.

Lastly, in recent years family offices and private investors with a family firm background increasingly seek direct investments in private family firms (Rottke \& Thiele, 2017). These investors might fit well with transactions in this quadrant as they possess values and identities consistent with those of a family firm. Family offices, just like family firms, are affected by family influence. While the main objective of a family office is to preserve the family's wealth and maintain its legacy, many family offices also place priority on objectives such as family harmony, cohesion and general continuity (Rivo-López, Villanueva-Villar, Vaquero-García, \&

\footnotetext{
${ }^{3}$ To protect their interests, mezzanine investors will typically restrict the family's latitude to execute capital reductions, alter dividend-policies, increase CEO compensation or attract more debt (Thompson \& Cusmano, 2013).
} 
Lago-Peñas, 2017). As such, they take a long-term view on investment and understand the importance of the continuation of family legacy and values. Furthermore, family offices that are not professionalized may have less formal control mechanisms (Wessel et al., 2014). This will resonate well with family owners who are concerned about the preservation of family influence over the firm as a source of SEW (Rottke \& Thiele, 2017). Overall, family offices might be the preferred choice for family firms seeking replacement capital as they have a more consistent business philosophy and similar understanding of the needs of the family business (Brueckner, 2014).

The importance of relational governance in the family-investor relationship will vary dependent on the type of investor. For mezzanine investors, who face lower risks than equity investors, contractual agreements rather than relational governance will guide relationships. Alternatively, for pure equity investors, relational governance with a focus on trust will play a key role (Rottke \& Thiele, 2017). Given the family owners' focus on transgenerational succession and preservation of SEW, a large part of the value the family will expect to generate from the cooperation will be of a non-contractible nature. The long-term horizon of family owners and their concern about the protection of family reputation provide increased incentives and ability to establish long-term trusting relationships (Arregle et al., 2007; Eddleston \& Morgan, 2014).

\section{Quadrant 4: Strategic Investment / Turn-Around}

In Quadrant 4, families are looking to strengthen the firm's capital and have a long-term investment time horizon. We distinguish between two scenarios. In one scenario, families seek a strategic partner to realize growth ambitions. We define these deals as strategic investments. In a 
second scenario, families may seek an investor to strengthen the firm's financial structure in a distress situation. We define these deals as turnarounds.

Strategic investments. In this scenario, families collaborate with an external investor to raise capital for the firm (time t1 in Figure 1) and have no immediate intention to exit. Transactions in this scenario take place when the firm perceives strategic investment opportunities that go beyond its immediate financing capacity. At the same time, the family has no wish to exit the firm, so typically the family will seek to buy out the outside investor when the growth has been realized.

A recent deal illustrating this scenario is the investment of LNK Partners (a New-York based PE firm) in Dogfish Head (a family owned and managed craft brewery in Delaware) in 2015 (Whipp \& Daneshkhu, 2016). Dogfish Head needed money and expertise to continue growing in an increasingly competitive market. Initially, however, the family owners were very sceptic about giving up control. The deal crystallized only after LNK agreed they would treasure DogFish Head's culture, the company would pursue "smart growth over fast growth," and the deal would not be a path to taking the company public. LNK acquired a 15 percent stake and got one seat on Dogfish Head's four-member board of directors.

From a family governance perspective, deals in this quadrant do not alter the family's level of wealth concentration. Furthermore, while investors and family owners will be aligned on the objective to pursue growth, conflicts may still occur because investors will generally be less concerned about SEW, be more willing to take risks, and have shorter time horizons. Because families are concerned about the retention of long-term family control, deals will typically involve minority investments. 
From a firm perspective, investors will focus on the realization of the firm's growth potential. The use of significant debt financing is less likely as the financial obligations associated with debt will limit the flexibility needed to pursue growth. Like in Quadrant 3, family owners will be unlikely to appoint a new external CEO. Family owners are in a strong position to negotiate and will prioritize the preservation of SEW including the continuation of family control over decision-making.

Deals in this quadrant only have limited fit with the traditional PE-model because families will generally prefer an investor with a long-term horizon. However, over the past years, some PE-firms have set up dedicated long-term funds for 20 years that can invest in companies for up to ten years. PE firms are rethinking old structures, giving themselves more time, and targeting returns of 10 to 12 per cent that are well below the 20 per cent returns usually aimed for by ten-year funds (The Economist, 2016). Some of these long-term oriented funds might be well suited for this type of transaction. Evergreen funds may also prove to be a good partner. Alternatively, if SEW-objectives are particularly pertinent, family offices and private investors with a family business background could provide a good fit. We anticipate that relational governance will be important in these transactions that involve long-term partnerships. The monetary incentives that come from equity ownership will not guarantee the alignment of family owners and investor on growth and SEW-related objectives.

Turnaround. Lastly, business-owning families may seek an equity investment because their firm is facing financial difficulties. Given the unpredictable outcome and the time and effort that might be needed to rescue the company, an exit will not be foreseen in the short term.

An example of a turnaround is the investment of Gimv (a quoted evergreen European PE firm) in Vandemoortele (a Belgian producer of bakery products) in 2009. The investment 
strengthened the balance sheet of Vandemoortele, which had suffered from a failed acquisition and lower revenues after the financial crisis. Supported by the investment, which involved subordinated debt with warrants, and after the divestment of an important business division, the fourth generation of the Vandemoortele family turned the tide. After seven successful years of growth and increased profitability, Gimv executed its warrants and sold its share to the Vandemoortele family who had pre-emption rights.

In turnarounds, the wealth concentration of family owners will remain constant or increase if they invest some of their private wealth along with the investor. Following the tenets of the behavioral agency model (Wiseman \& Gómez-Mejía, 1998), the likelihood of conflicts between outside investors and family shareholders may depend on the performance evolution of the firm. When the firm is in distress, investors and family owners will be aligned on a common objective, i.e. to increase the firm's profitability. Indeed, as the economic risks facing a family firm increase, the likelihood that economic considerations precede SEW considerations increases (Gómez-Mejía et al., 2007). ${ }^{4}$ Nevertheless, family owners and investors may still disagree about strategic alternatives, e.g. when considering laying off employees (Neckebrouck et al., 2016; Sraer \& Thesmar, 2007) or selling a division. Furthermore, conflicts between investors and the family will become more likely when firm performance increases. Relieved from financial distress, families may want to regain control over their firm and, if investors do not hold sufficient control rights, the latter will become vulnerable to expropriation. Concerning CEO replacement, attracting a new external CEO is a likely option and might be a condition imposed by the investor. Family owners are in a weak position and are forced to accept losses in SEW to

\footnotetext{
${ }^{4}$ Financial peril ultimately threatens the survival of the firm, which is the source of both the family's financial wealth and SEW (Chrisman \& Patel, 2012; Gómez-Mejía, Patel, \& Zellweger, 2018).
} 
guarantee firm survival. When selecting a new CEO, skills and experience with turnarounds will be most important.

PE investors specialized in distress will provide a good fit with this type of transactions. Their focus on efficiency improvements and cost-cutting initiatives, combined with experience in divestments, can help to solve financial distress (Hotchkiss, Strömberg, \& Smith, 2014). For family offices with a focus on the preservation of family wealth turnaround transactions might pose too much risk (Rottke \& Thiele, 2017). Relative to shareholder agreements and the monetary incentives that stem from ownership, relational governance mechanisms will only have a subordinate role. Given the focus on firm survival, most value of the cooperation will be of an economic nature.

\section{CONFIGURATIONS AS IDEAL TYPES}

While we focused our analysis on four distinct configurations, in practice, hybrid forms of transactions that cross the boundaries of individual quadrants may occur. Family owners, for instance, may seek external equity to provide liquidity for both the firm and the family. Following the foundations of configurational theory (Miles \& Snow, 1978), a real transaction does not need to be classified into one single quadrant however. Configurations should be interpreted as ideal-type organizations rather than as nominal categories. The ideal-type organization is an important theory-building device that can serve as "an abstract model so that deviation from the type can be noted and explained" (Blalock, 1969, p. 32). In our context, the degree of deviation between a real transaction and each ideal-type configuration can be used to predict governance performance. The performance of a particular configuration should decrease the more that configuration deviates from the ideal types (Drazin \& Van de Ven, 1985). 
Most configurational research in governance examines how different governance constellations lead to the same overarching objective of maximizing financial performance (e.g., Bell, Filatotchev, \& Aguilera, 2014). In such an approach, configurations are often derived empirically and scholars spend a lot of effort on inductively reasoning about the origin of the boundaries between the configurations. Our approach in contrast creates configurations that are more detached from each other. Each configuration originates from different, rather than one common, performance objectives: aiming for the continuation of family control rather than a family exit and providing liquidity for the family or for the firm. This implies that deals that overlap with multiple quadrants involve transactions in which the family has mixed objectives. For instance, family owners may wish to buy out other family members (as in Quadrant 3), whilst at the same time also increasing the firm's capital (as in Quadrant 4). In such a scenario, high-performing governance constellations will need to combine characteristics of different scenarios: an ideal investor should not only have high value-adding skills that support the realisation of profitable growth (as in Quadrant 4) but also allow the family to regain firm control over time (as in Quadrant 3).

\section{THEORETICAL PERSPECTIVES}

To study the investment cycle involving private family firms and external equity investors, including the selection of investors, screening, deal structuring, deal management, and deal performance, a wide variety of theoretical perspectives seem relevant. Given the heterogeneity in family-level objectives and resources, these investments are best understood by applying a multi-theoretic approach. Agency theory, stewardship theory and SEW perspectives may be complemented with multiple agency, resource dependence, strategic entrepreneurship, social identity, and trust-based perspectives. The configurational approach represents an ideal 
opportunity to bring to bear these perspectives while paying attention to organizational variations and the rich characterization of types and processes (Chrisman et al., 2018). Our configurational analysis shows how the relevance of individual governance perspectives varies across the different configurations. Below, we briefly discuss agency theory, multiple agency theory, resource dependence, strategic entrepreneurship, stewardship, social identity, SEW, and trustbased perspectives. Table 2 depicts the most relevant theoretical perspectives for each quadrant.

First, traditional agency theory will be relevant for different types of transactions as it focuses on the role of agency costs in family-owned firms and how investors implement governance structures to reduce those costs (Uhlaner et al., 2007). In most academic research on value creation in PE deals, researchers have focused on agency-based explanations arguing that PE firms increase efficiency by limiting managerial discretion (Jensen, 1989). While this view may be less relevant to private firms in which owners have strong incentives and ability to monitor management (Chung, 2011), the pursuit of SEW-objectives and associated inefficiencies likely increase the potential for efficiency gains in private family firms (Chrisman, Chua, Steier, et al., 2012). We anticipate that external investors will be able to focus most on the realization of efficiency gains in gradual exits in Quadrant 1.

Next to traditional agency theory, we lack applications of multiple agency theory including principal-principal agency theory. Multiple agency theory moves beyond a simplistic principal-agent dichotomy and considers multiple governance roles as agents and principals of the same participants in a transaction (Allcock \& Filatotchev, 2010; Arthurs et al., 2008; Deutsch, Keil, \& Laamanen, 2011). This may cause ambiguity in terms of whose interests are served (Hoskisson, Arthurs, White, \& Wyatt, 2013; Peng \& Sauerwald, 2013). For example, principal-principal conflicts might be prevalent when investors take a minority position in a 
family firm, which will be common in Quadrant 4a (Villalonga \& Amit, 2006). Additionally, in family firms involving outside investments, family members may play multiple roles as owner (principal), manager (agent), and potentially governor of the overall family wealth (agent and principal) which will lead to potentially conflicting incentives. Overall, more research is needed to examine the extent, heterogeneity and impact of principal-principal relationships in family firms involving outside investors. For example, what is the impact of the type of investor on the extent of principal-principal conflict and how will certain governance arrangements (e.g. CEO incentives) moderate this relationship.

While agency theory focuses on the efficiency of governance arrangements, resourcedependence theory assumes that power dependencies will take precedence in establishing governance arrangements (Pfeffer \& Salancik, 1978). From this perspective, investors in turnaround deals will have significant power in establishing government arrangements because firm survival depends on their provision of financial capital. Alternatively, when family owners are in a stronger position to negotiate, they will consider the resource dependencies investors impose on the family business when selecting a preferred investor. Families who prioritize the retention of long-term family control (as in Quadrant 3) might pick investors who exercise the least power, irrespective of the value creation potential. In this scenario, independent PE firms will probably be less preferred as potential partners given their typical use of formal control mechanisms including specific contracts and board representation.

A strategic entrepreneurship perspective recognizes that access to resources and capabilities are important drivers for family firms success (Ireland, Hitt, \& Sirmon, 2003). From this perspective, investors will help to address the dual challenges of sustaining current competitive advantage while pursuing new opportunities to contribute to the longevity of the 
family firm. Investors may provide complementary resources and capabilities that may be missing in the family business (Zahra \& Filatotchev, 2004). A key question is how investors impact the unique resource and resource-orchestration advantages of private family firms (Habbershon \& Williams, 1999; Sirmon, Hitt, Ireland, \& Gilbert, 2011). Overall, we anticipate that strategic entrepreneurship will be most relevant for Quadrants 2 and 4, i.e. deals with growth perspectives.

In contrast to agency theory, which assumes owners and managers are motivated by selfinterest, stewardship theory describes owners and managers as stewards who act in trustworthy, collectivistic and pro-organizational ways (Davis, Schoorman, \& Donaldson, 1997). Stewardship theory has been frequently applied to family firms (Corbetta \& Salvato, 2004; Le Breton-Miller et al., 2011). Stewardship theory implies that the family agenda includes the satisfaction of the goals of investors as a source of personal satisfaction (Davis et al., 1997). An intriguing question is how stewardship behavior may arise in the relationship between family owners and investors. Villanueva and Sapienza (2009) anticipate that stewardship behavior is more likely to arise when both family owners and investors have a broad agenda including both economic and noneconomic objectives. In that case, principles of reciprocity may govern the relationship and family owners and investors may tolerate each other's non-economic goals for common benefit (Villanueva \& Sapienza, 2009). These ideas suggest the need to examine how deal-making between family owners and investors may support the mediation of competing objectives. ${ }^{5}$ Overall, stewardship theory may be most relevant for deals that build on relational governance and that involve long-term partnerships such as strategic investments (Quadrant 4a).

\footnotetext{
${ }^{5}$ We thank an anonymous reviewer for this suggestion.
} 
Research recently applied social identity theory and organizational identification concepts to family firm decision-making (Cannella et al., 2015; Zellweger et al., 2013). Due to the role of the family business for the family's biography and the difficulty of the family to leave the firm, family members typically maintain a deep identification with their organizations (Dyer, 2006). Organizational identification may provide a relevant framework to examine the investment cycle involving family firms and outside investors. Family owners who strongly identify with their firm prefer family offices or private investors with a family business background as investors rather than PE sponsors because the former are less likely to disrupt the identity of the family (Neckebrouck et al., 2017). Social identity theory might be most relevant when families derive high levels of SEW from their identification with the firm as in Quadrants 3 and $4 \mathrm{a}$.

The SEW perspective gained great traction amongst family business scholars in the last decade with recent studies providing deep insights to how family firms balance economic and SEW objectives in their decision making (Gómez-Mejía et al., 2018; Kotlar et al., 2018). While family firm research traditionally assumes that ceding control involves strong losses in SEW (Gómez-Mejía et al., 2007), an intriguing question is whether replacement-capital deals that enable transgenerational successions (Quadrant 3) may actually increase SEW expectations (Kotlar et al., 2018). Overall, while SEW considerations may be prevalent across all quadrants, we anticipate they will be particularly influential when families have transgenerational intentions as in Quadrants 3 and 4 (Zellweger et al., 2012). We especially encourage research which disentangles the role of the different dimensions of SEW (Berrone et al., 2012) and which examines the relationship between specific family structures and SEW (Jaskiewicz et al., 2017). 
Lastly, we agree with Eddleston et al. (2010) and others (Arregle et al., 2007; Cruz et al., 2010) about the value of trust as a promising theoretical construct to advance understanding of family business governance. Trust represents the confidence that another party will refrain from exploiting the other's vulnerabilities even though the other has no control over it (Mayer, Davis, \& Schoorman, 1995). Cruz et al. (2010) argue that trust provides "a middle ground where agency theory and others-oriented theories can meet. Trust scholars do not assume that selfish opportunistic behavior is an always present danger, as conventional agency theory suggests, but "neither do they assume that opportunism is negligible, as stewardship theory proponents and other scholars suggest" (Cruz et al., 2010, p. 71). While research examined the unique value of trust within family firms (Steier, 2001), few studies focus on the role of trust in relationships of family firms with external stakeholders such as investors (Eddleston \& Morgan, 2014). Some studies imply that family firms have an advantage in establishing trusting relationships because they have higher standards of maintaining a favourable reputation (Craig, Dibrell, \& Davis, 2008). An intriguing question is whether and how trust-based governance mechanisms may interact with contractual governance mechanisms in family owner-investor relationships (Poppo \& Zenger, 2002). Overall, trust-based perspectives may be particularly relevant in deals characterized by long-term horizons and non-economic goals, such as in Quadrant 3 and 4a.

\section{CONCLUSION}

Scholars examining the role of external investors for family firms mostly examine PE buyouts of family firms but pay limited attention to scenarios in which private family firms cooperate with investors to accomplish their goals. Recognizing the diversity in objectives that may lead family firms to cede ownership to external investors, we developed a conceptual configuration model of four governance scenarios that may arise when family owners attract an 
external investor. Doing so, our model improves understanding about the evolving structures of ownership of private family firms, the increasingly heterogeneous PE funding landscape, and the role of alternative investors such as family offices. Our model also supports calls to take a more holistic configurational approach to research on family firm governance (Chrisman et al., 2018). To understand the consequences of external equity investments in private family firms, scholars may need to integrate multiple theoretical perspectives and direct attention to how various governance mechanisms combine effectively with each other, rather than merely considering governance mechanisms in isolation. We hope our insights stimulate future research on how external investors can contribute to private family firms, which constitute the world's most dominant form of organization. 


\section{REFERENCES}

Ahlers, O., Hack, A., \& Kellermanns, F. W. (2014). "Stepping into the buyers' shoes": Looking at the value of family firms through the eyes of private equity investors. Journal of Family Business Strategy, 5(4), 384-396.

Aldrich, H. E., \& Cliff, J. E. (2003). The pervasive effects of family on entrepreneurship: toward a family embeddedness perspective. Journal of Business Venturing, 18(5), 573-596.

Allcock, D., \& Filatotchev, I. (2010). Executive incentive schemes in initial public offerings: The effects of multiple-agency conflicts and corporate governance. Journal of Management, 36(3), 663-686.

Allio, M. K. (2004). Family businesses: their virtues, vices, and strategic path. Strategy \& Leadership, 32(4), 24-33.

Amore, M. D., Minichilli, A., \& Corbetta, G. (2011). How do managerial successions shape corporate financial policies in family firms? Journal of Corporate Finance, 17(4), 10161027.

Anderson, R. C., \& Reeb, D. M. (2003). Founding-family ownership, corporate diversification, and firm leverage. The Journal of Law and Economics, 46(2), 653-684.

Arregle, J.-L., Hitt, M. A., Sirmon, D. G., \& Very, P. (2007). The development of organizational social capital: Attributes of family firms. Journal of Management Studies, 44(1), 73-95.

Arthurs, J. D., Hoskisson, R. E., Busenitz, L. W., \& Johnson, R. A. (2008). Managerial agents watching other agents: Multiple agency conflicts regarding underpricing in IPO firms. Academy of Management Journal, 51(2), 277-294.

Barton, S. L., \& Gordon, P. J. (1987). Corporate strategy: Useful perspective for the study of capital structure? Academy of Management Review, 12(1), 67.

Barton, S. L., \& Gordon, P. J. (1988). Corporate strategy and capital structure. Strategic Management Journal, 9(6), 623-632.

Battistin, E., Bortoluzzi, P., Buttignon, F., \& Vedovato, M. (2017). Minority and majority private equity investments: firm performance and governance. Journal of Management \& Governance, 21(3), 659-684.

Bell, R. G., Filatotchev, I., \& Aguilera, R. V. (2014). Corporate Governance and Investors' Perceptions of Foreign IPO Value: An Institutional Perspective. Academy of Management Journal, 57(1), 301-320.

Berg, A., \& Gottschalg, O. F. (2005). Understanding value generation in buyouts. Journal of Restructuring Finance, 2(01), 9-37.

Berrone, P., Cruz, C., \& Gómez-Mejía, L. R. (2012). Socioemotional wealth in family firms: Theoretical dimensions, assessment approaches, and agenda for future research. Family Business Review, 25(3), 258-279.

Bertrand, M., \& Schoar, A. (2006). The Role of Family in Family Firms. Journal of Economic Perspectives, 20(2), 73-96.

Blalock, H. M. (1969). Theory construction: from verbal to mathematical formulations. PrenticeHall.

Brown, C., \& Kraeussl, R. (2012). Risk and return characteristics of listed private equity. The Oxford handbook of Private Equity. Oxford: Oxford University Press.

Brueckner, Y. (2014). Family Equity und M\&A: Familien als unternehmerische Direktinvestoren. $M \& A$ Review.

Campden Research, \& UBS. (2015). Global Family Office Report. 
Cannella, A. A., Jones, C. D., \& Withers, M. C. (2015). Family- versus lone-founder-controlled public corporations: Social identity theory and boards of directors. Academy of Management Journal, 58(2), 436-459.

Carney, M. (2005). Corporate governance and competitive advantage in family-controlled firms. Entrepreneurship Theory and Practice, 29(3), 249-265.

Chemla, G., Habib, M. A., \& Ljungqvist, A. (2007). An analysis of shareholder agreements. Journal of the European Economic Association, 5(1), 93-121.

Chrisman, J. J., Chua, J. H., Le Breton-Miller, I., Miller, D., \& Steier, L. P. (2018). Governance Mechanisms and Family Firms. Entrepreneurship Theory and Practice, 42(2), 171-186.

Chrisman, J. J., Chua, J. H., Pearson, A. W., \& Barnett, T. (2012). Family involvement, family influence, and family-centered non-economic goals in small firms. Entrepreneurship Theory and Practice, 36(2), 267-293.

Chrisman, J. J., Chua, J. H., Steier, L. P., Wright, M., \& McKee, D. N. (2012). An agency theoretic analysis of value creation through management buy-outs of family firms. Journal of Family Business Strategy, 3(4), 197-206.

Chrisman, J. J., \& Patel, P. C. (2012). Variations in R\&D investments of family and nonfamily firms: Behavioral agency and myopic loss aversion perspectives. Academy of Management Journal, 55(4), 976-997.

Chrisman, J. J., Sharma, P., Steier, L. P., \& Chua, J. H. (2013). The influence of family goals, governance, and resources on firm outcomes. Entrepreneurship Theory and Practice, $37(6), 1249-1261$.

Chung, J.-W. (2011). Leveraged buyouts of private companies. Retrieved April 7, 2017, from https://papers.ssrn.com/sol3/papers.cfm?abstract_id=1904342

Claessens, S., Djankov, S., \& Lang, L. H. (2000). The separation of ownership and control in East Asian corporations. Journal of Financial Economics, 58(1), 81-112.

Corbetta, G., \& Salvato, C. (2004). Self-serving or self-actualizing? Models of man and agency costs in different types of family firms: A commentary on "comparing the agency costs of family and non-family firms: Conceptual issues and exploratory evidence." Entrepreneurship Theory and Practice, 28(4), 355-362.

Craig, J. B., Dibrell, C., \& Davis, P. S. (2008). Leveraging family-based brand identity to enhance firm competitiveness and performance in family businesses. Journal of Small Business Management, 46(3), 351-371.

Croce, A., \& Martí, J. (2016). Productivity growth in private-equity-backed family firms. Entrepreneurship Theory and Practice, 40(3), 657-683.

Cruz, C. C., Gómez-Mejia, L. R., \& Becerra, M. (2010). Perceptions of benevolence and the design of agency contracts: CEO-TMT relationships in family firms. Academy of Management Journal, 53(1), 69-89.

Cumming, D., Schmidt, D., \& Walz, U. (2010). Legality and venture capital governance around the world. Journal of Business Venturing, 25(1), 54-72.

Cumming, D., Siegel, D. S., \& Wright, M. (2007). Private equity, leveraged buyouts and governance. Journal of Corporate Finance, 13(4), 439-460.

Daily, C. M., Dalton, D. R., \& Cannella, A. A. (2003). Corporate governance: Decades of dialogue and data. Academy of Management Review, 28(3), 371-382.

Davis, J. H., Allen, M. R., \& Hayes, H. D. (2010). Is blood thicker than water? A study of stewardship perceptions in family business. Entrepreneurship Theory and Practice, 34(6), 1093-1116. 
Davis, J. H., Schoorman, F. D., \& Donaldson, L. (1997). Toward a stewardship theory of management. Academy of Management Review, 22(1), 20.

Dawson, A. (2011). Private equity investment decisions in family firms: The role of human resources and agency costs. Journal of Business Venturing, 26(2), 189-199.

Deephouse, D. L., \& Jaskiewicz, P. (2013). Do family firms have better reputations than nonfamily firms? An integration of socioemotional wealth and social identity theories: corporate reputation in family firms. Journal of Management Studies, 50(3), 337-360.

Demsetz, H., \& Lehn, K. (1985). The structure of corporate ownership: Causes and consequences. Journal of Political Economy, 93(6), 1155-1177.

Deutsch, Y., Keil, T., \& Laamanen, T. (2011). A dual agency view of board compensation: The joint effects of outside director and CEO stock options on firm risk. Strategic Management Journal, 32(2), 212-227.

Di Toma, P., \& Montanari, S. (2012). Family business exit and private equity investment decisions: governance implications for value creation. Corporate Ownership and Control, 10, 466-484.

Drazin, R., \& Van de Ven, A. H. (1985). Alternative Forms of Fit in Contingency Theory. Administrative Science Quarterly, 30(4), 514-539.

Drover, W., Busenitz, L., Matusik, S., Townsend, D., Anglin, A., \& Dushnitsky, G. (2017). A review and road map of entrepreneurial equity financing research: Venture capital, corporate venture capital, angel investment, crowdfunding, and accelerators. Journal of Management, 43(6), 1820-1853.

Dyer, W. G. (2006). Examining the "family effect" on firm performance. Family Business Review, 19(4), 253-273.

Eddleston, K. A., Chrisman, J. J., Steier, L. P., \& Chua, J. H. (2010). Governance and trust in family firms: An introduction. Entrepreneurship Theory and Practice, 34(6), 1043-1056.

Eddleston, K. A., \& Morgan, R. M. (2014). Trust, commitment and relationships in family business: Challenging conventional wisdom. Journal of Family Business Strategy, 5(3), 213-216.

Fama, E. F., \& Jensen, M. C. (1983). Separation of ownership and control. The Journal of Law and Economics, 26(2), 301-325.

Firfiray, S., Cruz, C., Neacsu, I., \& Gomez-Mejia, L. R. (2017). Is nepotism so bad for family firms? A socioemotional wealth approach. Human Resource Management Review. Retrieved July 28, 2017, from http://linkinghub.elsevier.com/retrieve/pii/S1053482217300402

Forbes. (2014). Inside the billionaire family feud that nearly killed market basket. Forbes. Retrieved November 22, 2017, from https://www.forbes.com/sites/hollieslade/2014/09/10/inside-the-billionaire-family-feudthat-nearly-killed-market-basket/

Gallo, M. Á., Tàpies, J., \& Cappuyns, K. (2004). Comparison of family and nonfamily business: Financial logic and personal preferences. Family Business Review, 17(4), 303-318.

Gedajlovic, E., \& Carney, M. (2010). Markets, hierarchies, and families: Toward a transaction cost theory of the family firm. Entrepreneurship Theory and Practice, 34(6), 1145-1172.

Gómez-Mejía, L. R., Cruz, C., Berrone, P., \& De Castro, J. (2011). The bind that ties: Socioemotional wealth preservation in family firms. Academy of Management Annals, $5(1), 653-707$. 
Gómez-Mejía, L. R., Haynes, K. T., Núñez-Nickel, M., Jacobson, K. J. L., \& Moyano-Fuentes, J. (2007). Socioemotional wealth and business risks in family-controlled firms: Evidence from Spanish olive oil mills. Administrative Science Quarterly, 52(1), 106-137.

Gómez-Mejía, L. R., Makri, M., \& Kintana, M. L. (2010). Diversification decisions in familycontrolled firms. Journal of Management Studies, 47(2), 223-252.

Gómez-Mejía, L. R., Nuñez-Nickel, M., \& Gutierrez, I. (2001). The role of family ties in agency contracts. Academy of Management Journal, 44(1), 81-95.

Gómez-Mejía, L. R., Patel, P. C., \& Zellweger, T. M. (2018). In the horns of the dilemma: Socioemotional wealth, financial wealth, and acquisitions in family firms. Journal of Management, 44(4), 1369-1397.

Habbershon, T. G., \& Williams, M. L. (1999). A resource-based framework for assessing the strategic advantages of family firms. Family Business Review, 12(1), 1-25.

Hoskisson, R. E., Arthurs, J. D., White, R. E., \& Wyatt, C. (2013). Multiple agency theory: An emerging perspective of corporate governance. Oxford Handbook of Corporate Governance. Oxford: Oxford University Press.

Hoskisson, R. E., Shi, W., Yi, X., \& Jin, J. (2013). The evolution and strategic positioning of private equity firms. Academy of Management Perspectives, 27(1), 22-38.

Hotchkiss, E. S., Strömberg, P., \& Smith, D. C. (2014). Private equity and the resolution of financial distress. AFA 2012 Chicago Meetings Paper. Retrieved July 11, 2016, from http://papers.ssrn.com/sol3/Papers.cfm?abstract_id=1787446

Howorth, C., Westhead, P., \& Wright, M. (2004). Buyouts, information asymmetry and the family management dyad. Journal of Business Venturing, 19(4), 509-534.

Howorth, C., Wright, M., Westhead, P., \& Allcock, D. (2016). Company metamorphosis: professionalization waves, family firms and management buyouts. Small Business Economics, 47(3), 803-817.

Ireland, R. D., Hitt, M. A., \& Sirmon, D. G. (2003). A model of strategic entrepreneurship: The construct and its dimensions. Journal of Management, 29(6), 963-989.

Jaskiewicz, P., Combs, J. G., Shanine, K. K., \& Kacmar, K. M. (2017). Introducing the family: A review of family science with implications for management research. Academy of Management Annals, 11(1), 309-341.

Jensen, M. C. (1989). Eclipse of the public corporation. Harvard Business Review, 67(5), 61-74.

Jensen, M. C. (1993). The modern industrial revolution, exit, and the failure of internal control systems. The Journal of Finance, 48(3), 831-880.

Jensen, M. C., \& Meckling, W. H. (1976). Theory of the firm: Managerial behavior, agency costs and ownership structure. Journal of Financial Economics, 3(4), 305-360.

Kaplan, S. N. (1989). The effects of management buyouts on operating performance and value. Journal of Financial Economics, 24(2), 217-254.

Kaplan, S. N., \& Strömberg, P. (2009). Leveraged buyouts and private equity. The Journal of Economic Perspectives, 23(1), 121-146.

King, M. R., \& Santor, E. (2008). Family values: Ownership structure, performance and capital structure of Canadian firms. Journal of Banking \& Finance, 32(11), 2423-2432.

König, A., Kammerlander, N., \& Enders, A. (2013). The family innovator's dilemma: How family influence affects the adoption of discontinuous technologies by incumbent firms. Academy of Management Review, 38(3), 418-441. 
Koropp, C., Grichnik, D., \& Kellermanns, F. (2013). Financial attitudes in family firms: The moderating role of family commitment. Journal of Small Business Management, 51(1), 114-137.

Kotlar, J., Signori, A., De Massis, A., \& Vismara, S. (2018). Financial wealth, socioemotional wealth, and IPO underpricing in family firms: A two-stage gamble model. Academy of Management Journal, 61(3), 1073-1099.

La Porta, R., Lopez-De-Silanes, F., \& Shleifer, A. (1999). Corporate ownership around the world. The Journal of Finance, 54(2), 471-517.

Le Breton-Miller, I., Miller, D., \& Lester, R. H. (2011). Stewardship or agency? A social embeddedness reconciliation of conduct and performance in public family businesses. Organization Science, 22(3), 704-721.

López-Gracia, J., \& Sánchez-Andújar, S. (2007). Financial structure of the family business: evidence from a group of small Spanish firms. Family Business Review, 20(4), 269-287.

Mahérault, L. (2004). Is there any specific equity route for small and medium-sized family businesses? The french experience. Family Business Review, 17(3), 221-235.

Manigart, S., De Waele, K., Wright, M., Robbie, K., Desbrières, P., J Sapienza, H., \& Beekman, A. (2002). Determinants of required return in venture capital investments: A five-country study. Journal of Business Venturing, 17, 291-312.

Manigart, S., \& Wright, M. (2013). Reassessing the relationships between private equity investors and their portfolio companies. Small Business Economics, 40(3), 479-492.

Martin, G., Gómez-Mejía, L. R., Berrone, P., \& Makri, M. (2017). Conflict between controlling family owners and minority shareholders: Much ado about nothing? Entrepreneurship Theory and Practice, 41(6), 999-1027.

Mayer, R. C., Davis, J. H., \& Schoorman, F. D. (1995). An integrative model of organizational trust. Academy of Management Review, 20(3), 709-734.

Meuleman, M., Amess, K., Wright, M., \& Scholes, L. (2009). Agency, strategic entrepreneurship, and the performance of private equity-backed buyouts. Entrepreneurship Theory and Practice, 33(1), 213-239.

Meyer, A. D., Tsui, A. S., \& Hinings, C. R. (1993). Configurational approaches to organizational analysis. Academy of Management Journal, 36(6), 1175-1195.

Miles, R. E., \& Snow, C. C. (1978). Organizational strategy, structure, and process (1 edition.). Stanford, Calif: Stanford Business Books.

Miller, D., Friesen, P. H., \& Mintzberg, H. (1984). Organizations: A quantum view. PrenticeHall.

Miller, D., Le Breton-Miller, I., \& Lester, R. H. (2011). Family and Lone Founder Ownership and Strategic Behaviour: Social Context, Identity, and Institutional Logics. Journal of Management Studies, 48(1), 1-25.

Misangyi, V. F., \& Acharya, A. G. (2014). Substitutes or complements? A configurational examination of corporate governance mechanisms. Academy of Management Journal, 57(6), 1681-1705.

Molly, V., Laveren, E., \& Jorissen, A. (2012). Intergenerational differences in family firms: Impact on capital structure and growth behavior. Entrepreneurship Theory and Practice, 36(4), 703-725.

Morck, R., \& Yeung, B. (2003). Agency problems in large family business groups. Entrepreneurship Theory and Practice, 27(4), 367-382. 
Naldi, L., Cennamo, C., Corbetta, G., \& Gomez-Mejia, L. (2013). Preserving socioemotional wealth in family firms: asset or liability? The moderating role of business context. Entrepreneurship Theory and Practice, 37(6), 1341-1360.

Neckebrouck, J., Manigart, S., \& Meuleman, M. (2017). Attitudes of family firms toward outside investors: The importance of organizational identification. Venture Capital, 19(1-2), 2950 .

Neckebrouck, J., Manigart, S., \& Meuleman, M. L. (2016). Working for divergent principals: Effects of private equity on employment practices in family firms. Academy of Management Proceedings, 2016(1), 16002.

Neckebrouck, J., Schulze, W., \& Zellweger, T. (2018). Are family firms good employers? Academy of Management Journal, 61(2), 553-585.

Nordqvist, M. (2005). Familiness in top management teams: commentary on Ensley and Pearson's “An exploratory comparison of the behavioral dynamics of top management teams in family and nonfamily new ventures: cohesion, conflict, potency, and consensus." Entrepreneurship Theory and Practice, 29(3), 285-291.

OECD. (2012). Financing SMEs and entrepreneurs 2012. Paris: Organisation for Economic Cooperation and Development. Retrieved from http://www.oecdilibrary.org/content/book/9789264166769-en

Peng, M. W., \& Sauerwald, S. (2013). Corporate governance and principal-principal conflicts. The Oxford Handbook of Corporate Governance. Oxford: Oxford University Press.

Pfeffer, J., \& Salancik, G. R. (1978). The external control of organizations: A resource dependence approach. New York: Harper and Row.

Poppo, L., \& Zenger, T. (2002). Do formal contracts and relational governance function as substitutes or complements? Strategic Management Journal, 23(8), 707-725.

Poutziouris, P. Z. (2001). The views of family companies on venture capital: Empirical evidence from the UK small to medium-size enterprising economy. Family Business Review, 14(3), 277-291.

Private Equity Wire. (2017). Arlington Capital Partners acquires Molecular Products Group. Private Equity Wire. Retrieved November 22, 2017, from https://www.privateequitywire.co.uk/2017/01/06/247293/arlington-capital-partnersacquires-molecular-products-group

Rediker, K. J., \& Seth, A. (1995). Boards of directors and substitution effects of alternative governance mechanisms. Strategic Management Journal, 16(2), 85-99.

Renneboog, L., Simons, T., \& Wright, M. (2007). Why do public firms go private in the UK? The impact of private equity investors, incentive realignment and undervaluation. Journal of Corporate Finance, 13(4), 591-628.

Rivo-López, E., Villanueva-Villar, M., Vaquero-García, A., \& Lago-Peñas, S. (2017). Family offices. Organizational Dynamics, 46(4), 262-270.

Romano, C. A., Tanewski, G. A., \& Smyrnios, K. X. (2001). Capital structure decision making: A model for family business. Journal of Business Venturing, 16(3), 285-310.

Rottke, O. M., \& Thiele, F. K. (2017). Do family investors differ from other investors? Similarity, experience, and professionalism in the light of family investee firm challenges. Journal of Business Economics. Retrieved November 21, 2017, from https://link.springer.com/article/10.1007/s11573-017-0871-7 
Schiehll, E., Lewellyn, K. B., \& Muller-Kahle, M. I. (2017). Pilot, pivot and advisory boards: The role of governance configurations in innovation commitment. Organization Studies, 0170840617717092.

Schmohl, J. (2010). Entrepreneurial exit management: Key success factors of the private equity buyout option. Dissertation - University of St. Gallen, .

Scholes, L., Wright, M., Westhead, P., \& Bruining, H. (2010). Strategic changes in family firms post management buyout: Ownership and governance issues. International Small Business Journal, 28(5), 505-521.

Schulze, W. S., Lubatkin, M. H., \& Dino, R. N. (2003a). Exploring the agency consequences of ownership dispersion among the directors of private family firms. Academy of Management Journal, 46(2), 179-194.

Schulze, W. S., Lubatkin, M. H., \& Dino, R. N. (2003b). Toward a theory of agency and altruism in family firms. Journal of Business Venturing, 18(4), 473-490.

Schulze, W. S., Lubatkin, M. H., Dino, R. N., \& Buchholtz, A. K. (2001). Agency relationships in family firms: Theory and evidence. Organization Science, 12(2), 99-116.

Sirmon, D. G., \& Hitt, M. A. (2003). Managing resources: Linking unique resources, management, and wealth creation in family firms. Entrepreneurship Theory and Practice, 27(4), 339-358.

Sirmon, D. G., Hitt, M. A., Ireland, R. D., \& Gilbert, B. A. (2011). Resource orchestration to create competitive advantage: Breadth, depth, and life cycle effects. Journal of Management, 37(5), 1390-1412.

Sraer, D., \& Thesmar, D. (2007). Performance and behavior of family firms: Evidence from the French stock market. Journal of the European Economic Association, 5(4), 709-751.

Stanley, L. J., \& McDowell, W. (2014). The role of interorganizational trust and organizational efficacy in family and nonfamily firms. Journal of Family Business Strategy, 5(3), 264275.

Steier, L. P. (2001). Family firms, plural forms of governance, and the evolving role of trust. Family Business Review, 14(4), 353-368.

Steier, L. P., Chua, J. H., \& Chrisman, J. J. (2009). Embeddedness perspectives of economic action within family firms. Entrepreneurship Theory and Practice, 33(6), 1157-1167.

The Economist. (2016). The Omaha play. The Economist. Retrieved from https://www.economist.com/news/finance-and-economics/21706506-buy-out-firms-areseeking-out-longer-term-investments-omaha-play

Thompson, J., \& Cusmano, L. (2013). Alternative financing instruments for SMEs and entrepreneurs: The case of mezzanine financing (OECD SME and Entrepreneurship Papers No. 2). Retrieved May 14, 2018, from http://www.oecdilibrary.org/economics/alternative-financing-instruments-for-smes-andentrepreneurs_3709429e-en

Torpey, W. J., \& Viscione, J. A. (1987). Mezzanine money for smaller businesses. Harvard Business Review, 65(3), 116-116.

Uhlaner, L., Wright, M., \& Huse, M. (2007). Private firms and corporate governance: An integrated economic and management perspective. Small Business Economics, 29(3), 225-241.

Verbeke, A., \& Kano, L. (2012). The transaction cost economics theory of the family firm: Family-based human asset specificity and the bifurcation bias. Entrepreneurship Theory and Practice, 36(6), 1183-1205. 
Villalonga, B. (2012). Note on financing growth in family firms. Retrieved November 21, 2017, from http://www.hbs.edu/faculty/Pages/item.aspx?num=42617

Villalonga, B., \& Amit, R. (2006). How do family ownership, control and management affect firm value? Journal of Financial Economics, 80(2), 385-417.

Villanueva, J., \& Sapienza, H. J. (2009). Goal tolerance, outside investors, and family firm governance. Entrepreneurship Theory and Practice, 33(6), 1193-1199.

Volpin, P. F. (2002). Governance with poor investor protection: evidence from top executive turnover in Italy. Journal of Financial Economics, 64(1), 61-90.

Wennberg, K., Wiklund, J., Hellerstedt, K., \& Nordqvist, M. (2011). Implications of intra-family and external ownership transfer of family firms: short-term and long-term performance differences. Strategic Entrepreneurship Journal, 5(4), 352-372.

Wessel, S., Decker, C., Lange, K. S. G., \& Hack, A. (2014). One size does not fit all: Entrepreneurial families' reliance on family offices. European Management Journal, 32(1), 37-45.

Whipp, L., \& Daneshkhu, S. (2016, October 26). Brewing: Craft beer comes of age. Financial Times. Retrieved November 22, 2017, from https://www.ft.com/content/c9f77348-8ccc11e6-8cb7-e7ada1d123b1

Wiklund, J., Nordqvist, M., Hellerstedt, K., \& Bird, M. (2013). Internal versus external ownership transition in family firms: An embeddedness perspective. Entrepreneurship Theory and Practice, 37(6), 1319-1340.

Wiseman, R. M., \& Gómez-Mejía, L. R. (1998). A behavioral agency model of managerial risk taking. Academy of Management Review, 23(1), 133-153.

Wood, G., \& Wright, M. (2009). Private equity: A review and synthesis. International Journal of Management Reviews, 11(4), 361-380.

Wright, M., Amess, K., Weir, C., \& Girma, S. (2009). Private equity and corporate governance: Retrospect and prospect. Corporate Governance: An International Review, 17(3), 353375.

Wright, M., Hoskisson, R. E., \& Busenitz, L. W. (2001). Firm rebirth: Buyouts as facilitators of strategic growth and entrepreneurship. Academy of Management Executive, 15(1), 111125.

Wright, M., Hoskisson, R. E., Busenitz, L. W., \& Dial, J. (2000). Entrepreneurial growth through privatization: The upside of management buyouts. Academy of Management Review, 25(3), 591-601.

Wu, Z., Chua, J. H., \& Chrisman, J. J. (2007). Effects of family ownership and management on small business equity financing. Journal of Business Venturing, 22(6), 875-895.

Young, M. N., Peng, M. W., Ahlstrom, D., Bruton, G. D., \& Jiang, Y. (2008). Corporate governance in emerging economies: A review of the principal-principal perspective. Journal of Management Studies, 45(1), 196-220.

Zahra, S. A., \& Filatotchev, I. (2004). Governance of the entrepreneurial threshold firm: A knowledge-based perspective. Journal of Management Studies, 41(5), 885-897.

Zellweger, T. M., Kellermanns, F. W., Chrisman, J. J., \& Chua, J. H. (2012). Family control and family firm valuation by family CEOs: The importance of intentions for transgenerational control. Organization Science, 23(3), 851-868.

Zellweger, T. M., Nason, R. S., Nordqvist, M., \& Brush, C. G. (2013). Why do family firms strive for nonfinancial goals? An organizational identity perspective. Entrepreneurship Theory and Practice, 37(2), 229-248. 
Table 1

Governance implications and investor type

\begin{tabular}{|c|c|c|c|c|c|}
\hline & Quadrant 1 & Quadrant 2 & Quadrant 3 & Quadrant 4a & Quadrant 4b \\
\hline & $\begin{array}{l}\text { Gradual } \\
\text { exit }\end{array}$ & Extend the firm & $\begin{array}{l}\text { Replacement } \\
\text { capital }\end{array}$ & $\begin{array}{l}\text { Strategic } \\
\text { investment }\end{array}$ & Turnaround \\
\hline \multicolumn{6}{|l|}{ Governance implications } \\
\hline \multicolumn{6}{|l|}{ Family perspective } \\
\hline $\begin{array}{l}\text { Wealth concentration remaining } \\
\text { family }\end{array}$ & $\begin{array}{l}\text { Constant or } \\
\text { decrease }\end{array}$ & Constant & $\begin{array}{l}\text { Constant or } \\
\text { increase }\end{array}$ & Constant & $\begin{array}{l}\text { Constant or } \\
\text { increase }\end{array}$ \\
\hline Investment time horizon & $\begin{array}{l}\text { Medium } \\
\text { term }\end{array}$ & Medium term & Long term & Long term & Medium term \\
\hline $\begin{array}{l}\text { Family's focus on socioemotional } \\
\text { wealth }\end{array}$ & Low & Low & High & Medium & Low \\
\hline \multicolumn{6}{|l|}{ Firm perspective } \\
\hline Focus on efficiency & High & Medium & Low & Low & High \\
\hline Focus on growth & Low & High & Low & High & Low \\
\hline Use of debt & Medium & Low & High & Low & Low \\
\hline $\begin{array}{l}\text { Reduced family involvement in } \\
\text { management }\end{array}$ & Possibly & Possibly & Unlikely & Unlikely & Likely \\
\hline Focus on relational governance & Low & Low & Medium & High & Low \\
\hline Investor type & $\begin{array}{l}\text { Independent } \\
\text { PE, Bank- } \\
\text { affiliated PE }\end{array}$ & $\begin{array}{l}\text { Independent PE, } \\
\text { Evergreen PE }\end{array}$ & $\begin{array}{l}\text { Mezzanine PE, } \\
\text { Bank-affiliated } \\
\text { PE, } \\
\text { Government } \\
\text { PE, Family } \\
\text { office }\end{array}$ & $\begin{array}{l}\text { Evergreen PE } \\
\text { Long-term PE } \\
\text { Government } \\
\text { PE, Family } \\
\text { office }\end{array}$ & $\begin{array}{l}\text { Turnaround } \\
\text { PE }\end{array}$ \\
\hline
\end{tabular}

Table 2

Most relevant theoretical perspectives

\begin{tabular}{|c|c|c|c|c|c|}
\hline & Quadrant 1 & Quadrant 2 & Quadrant 3 & Quadrant 4a & Quadrant 4b \\
\hline & $\begin{array}{l}\text { Gradual } \\
\text { exit }\end{array}$ & $\begin{array}{l}\text { Spruce-up } \\
\text { the firm }\end{array}$ & $\begin{array}{l}\text { Replacement } \\
\text { capital }\end{array}$ & $\begin{array}{l}\text { Strategic } \\
\text { investment }\end{array}$ & Turnaround \\
\hline $\begin{array}{l}\text { Most relevant theoretical } \\
\text { perspectives }\end{array}$ & $\begin{array}{l}\text { Agency } \\
\text { theory }\end{array}$ & $\begin{array}{l}\text { Strategic } \\
\text { entrepreneurship }\end{array}$ & $\begin{array}{l}\text { Stewardship, } \\
\text { socioemotional } \\
\text { wealth, social } \\
\text { identity, trust }\end{array}$ & $\begin{array}{l}\text { Strategic } \\
\text { entrepreneursh } \\
\text { ip, multiple } \\
\text { agency, } \\
\text { socioemotiona } \\
1 \text { wealth, } \\
\text { social identity, } \\
\text { trust }\end{array}$ & $\begin{array}{l}\text { Resource } \\
\text { dependence } \\
\text { theory, agency } \\
\text { theory, } \\
\text { multiple } \\
\text { agency theory }\end{array}$ \\
\hline
\end{tabular}


Figure 1. Configurational Model for External Equity Investments in Family Firms 


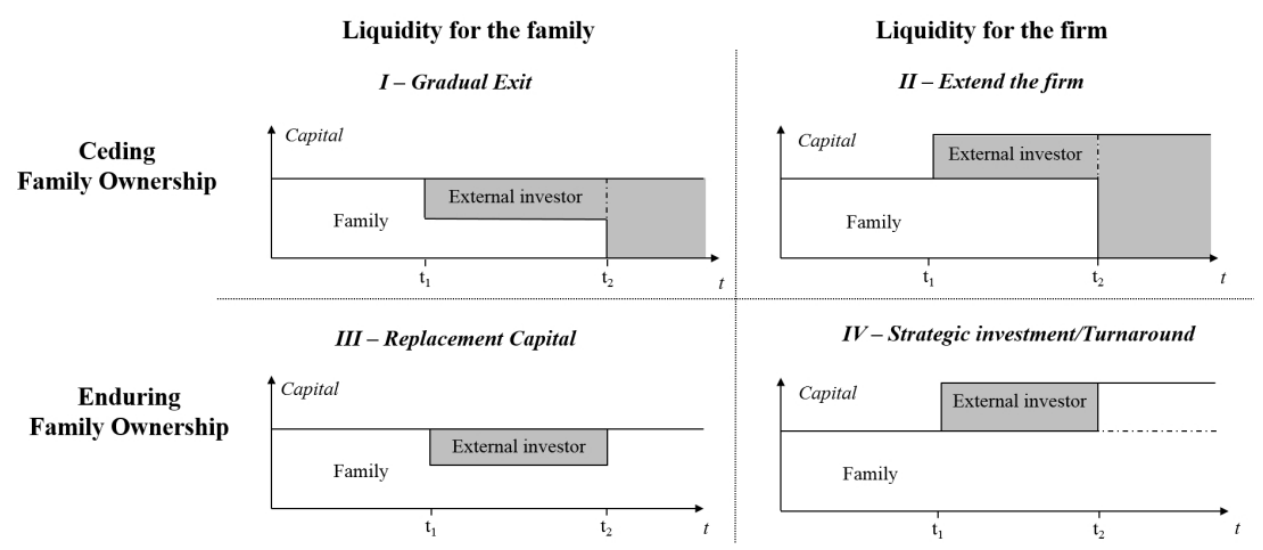

$329 \times 146 \mathrm{~mm}(150 \times 150 \mathrm{DPI})$ 